\title{
TÖBBSZABADSÁGFOKÚ, NEM RUGALMAS ANYAGÚ RENDSZEREK DINAMIKAI STABILITÁSI ÁLLAPOTA (RÁZÓASZTAL KÍSÉRLETEK*)
}

\author{
DR. DULÁCSKA ENDRE
}

\begin{abstract}
BEVEZETÉS
A földrengés elleni méretezésnél a képlékeny elmozdulás (duktilitás) kedvezőnek vélt hatását világszerte figyelembe veszik oly módon, hogy a $\mu=\Delta_{\mathrm{u}} / \Delta_{\mathrm{e}}$ duktilitási tényezővel elosztják a rugalmas rendszerre múködő, a földrengést helyettesítő horizontális erőt. A duktilitási tényező kifejezésében $\Delta_{\mathrm{u}}$ a képlékeny, és $\Delta_{\mathrm{e}}$ a rugalmas alakváltozás határa. A figyelembe, ill. számításba vett duktilitási tényező 2-12 között változik, az USA-ban például vasbetonszerkezetekre 8 értékủ. Ennek az eredménye, hogy az épületeket alacsony teherszinten rugalmas állapotban vizsgálják, így a mozgások kicsik, és emiatt a függőleges teher horizontális elmozdulást növelö kedvezőtlen hatását vagy elhanyagolják, vagy csak közelítően (lineáris hatásként) veszik figyelembe. Valójában a képlékenység és a kihajlás nem lineáris jelenség, és nem szabad őket szuperponálni. Az elméleti vizsgálatok szerint ez súlyos hiba a biztonság kárára. E szokásos eljárásnak az a következménye, hogy az egész világon nagyszámú, földrengésre méretezett épület megy tönkre, vagy omlik össze, emberek tízezreit temetve maguk alá.

A kérdés tisztázására egy előző OTKA pályázat [1] keretében a számítás pontosítására a függőleges teher nyomatéknövelő hatásának figyelembevételével különböző vizsgálatokat végeztünk egy olyan rugalmas-képlékeny, egyszabadságfokú, az impulzusgerjesztésen kívül függőleges erővel is terhelt modellel, melynek duktilitási tényezője 12 volt. A vizsgálatokat egyrészt elméleti, másrészt kísérleti úton végeztük el. Az elméleti számításokat egyrészt energiamódszerrel, másrészt a mozgási differenciálegyenlet step-by-step módszerrel való megoldásával végeztük. A számítási eredményeket mintegy tizenöt impulzusgerjesztésủ kísérlettel ellenőriztük.
\end{abstract}

* A dolgozat az OTKA 015701 sz. kutatás keretében készült. Témavezető: Dr. Dulácska Endre, kutatók: Dr. Bognár László, Dr. Csák Béla, munkatársak: Dr. Sajtos István, Macskási Réka, Péczely Attila, Gábor Áron, ifj.Turi László, Sebestyén Ottó.

A müszaki tudomány doktora, Széchenyi díjas okl. építészmérnök, egyetemi tanár, az MTA Földrengésmérnöki EAEE Magyar Nemzeti Bizottságának elnöke. 
A számítási, ill. kísérleti modell adatai a 1. ábrán, az eredmények a 2. ábrán láthatók.
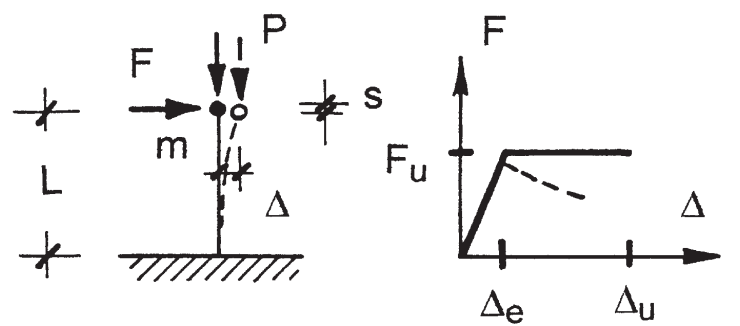

$$
\begin{aligned}
& \mu=\Delta_{\mathrm{u}} / \Delta_{\mathrm{e}} \\
& \Delta \mathrm{M}=\mathrm{P} \cdot \Delta
\end{aligned}
$$

Adatok: rugóállandó $=\mathrm{k}=15700 \mathrm{~N} / \mathrm{m}, \mathrm{m}=235 \mathrm{~kg}$.

$$
\begin{aligned}
& \mathrm{P}=2350 \mathrm{~N}, \mathrm{P}_{\mathrm{cr}}=16480 \mathrm{~N}, \mathrm{~L}=1,05 \mathrm{~m}, \mathrm{t}_{\mathrm{o}}=0,15 \mathrm{sec}, \\
& \Delta_{\mathrm{e}}=0,045 \mathrm{~m}, \Delta_{\mathrm{u}}=0,54 \mathrm{~m}, \Delta_{\mathrm{cr}}=0,22 \mathrm{~m}, \mu=12
\end{aligned}
$$

1. ábra. Az egyszabadságfokú modell

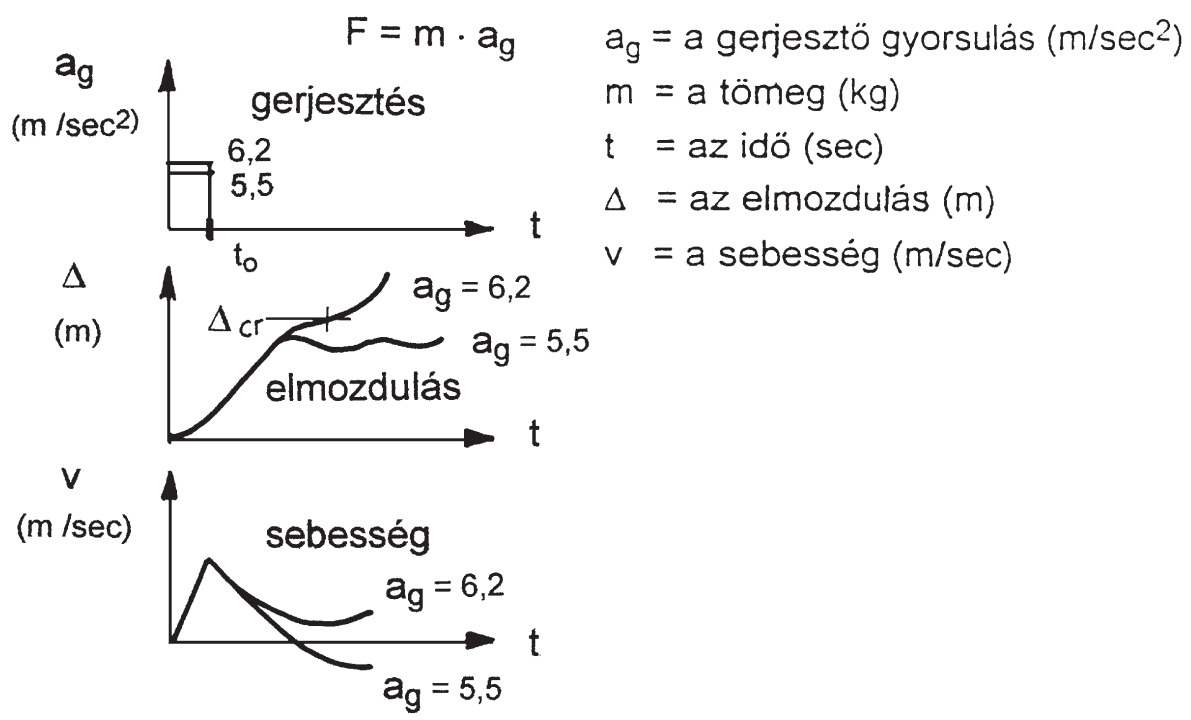

2. ábra. A különböző impulzussal gerjesztett szerkezet viselkedése 
Az eredményekből látható, hogy az impulzusnak (lökőerőnek) van egy kritikus értéke, mely után a mozgás végtelenhez tart, ugyanakkor a sebesség nem csökken zérusra, így a lengés nem áll meg. A számítási, ill. kísérleti eredmények alapján fel lehetett szerkeszteni a szerkezet $\beta$ elmozdulási válasz-spektrumát (a dinamikus tényezőt), amelyet a 3. ábra vázol.

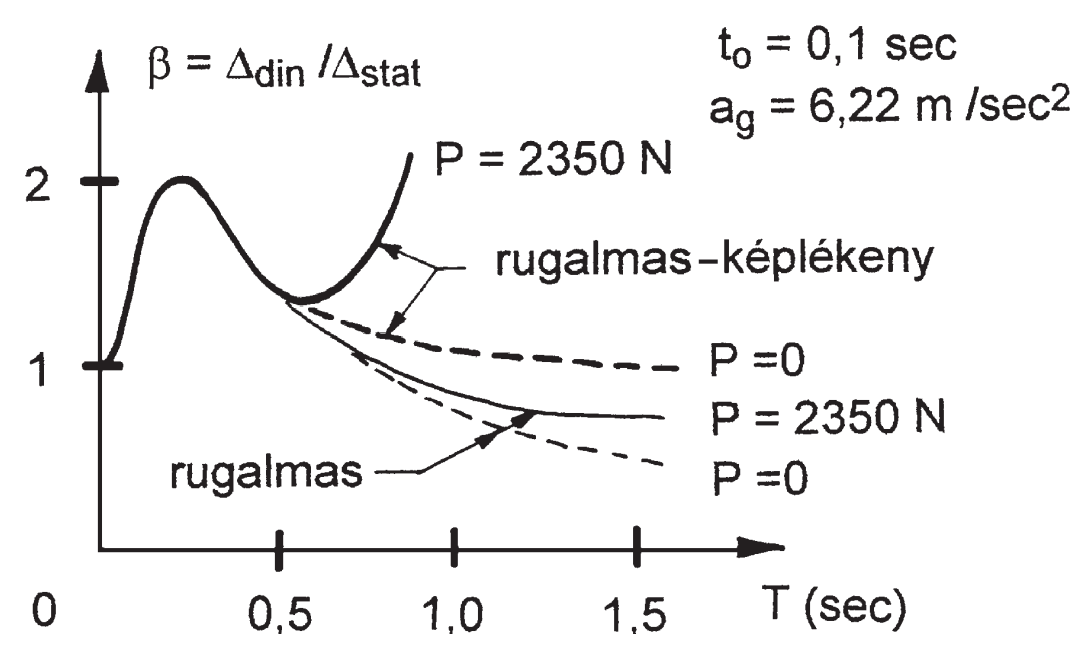

3. ábra. A rugalmas és rugalmas-képlékeny szerkezet elmozdulási válasz-spektruma

Látható, hogy a rugalmas-képlékeny anyagú szerkezet elmozdulási válaszspektruma a T periódusidő növekedésével a végtelenhez kanyarodik, szemben a rugalmas spektrummal, mely monoton csökken.

Vizsgálatokat végeztünk a véletlenszerúen gerjesztett modell viselkedésének tisztázására is. Az elméleti vizsgálatokhoz a véletlenrezgés elméletet a valószínüségelmélettel kombinálva alkalmaztuk, és mintegy száz, fehérzajjal gerjesztett kísérletet végeztünk. Az eredmények azt mutatták, hogy alapvető különbség van a nyomóerővel nem terhelt és a P nyomóerővel terhelt szerkezet viselkedése között. Az alkalmazott nyomóerő (gravitációs tömegerő) a kritikus erőnek mindössze 5\%a volt. (A valóságos szerkezetek terhe ennél sokkal jobban megközelíti a kritikus erőt.) Már ez a kis nyomóerő hatás is azt eredményezte, hogy míg a $\mathrm{P}=0$ esetben a képlékeny elmozdulás után a rúd a görbült helyzetben tovább rezeg, és ez az állapot stabil marad, a $\mathrm{P} \neq 0$ esetben az alakváltozás fokozatosan növekszik, és a rúd egyensúlyi helyzete instabil. Az egyik ilyen modell kísérleti eredményét láthatjuk a 4. ábrán. 


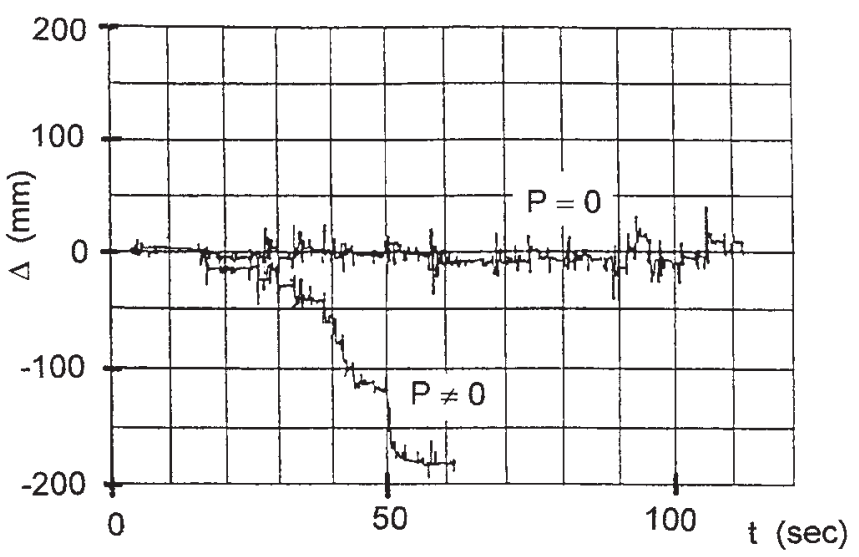

4. ábra. A véletlenrezgéssel gerjesztett modell elmozdulása $P=0$ és $P \neq 0$ esetében

A kísérletek során bebizonyosodott, hogy hasonlóan a világszerte folytatott vizsgálatokhoz, a rezgés során szilárdságdegradáció következik be, azaz a szerkezet ellenállása a plasztifikálódás után nem állandó, mint ahogy azt a duktilitási elmélet feltételezi, hanem fokozatosan csökken. Egy ilyen degradációs jellegú kísérleti diagramot mutat az 5. ábra. A degradáció már önmagában nemlineárissá teszi a feladatot, és ehhez járul még az anyagi (duktilitási) és a geometriai nemlineáris hatás.

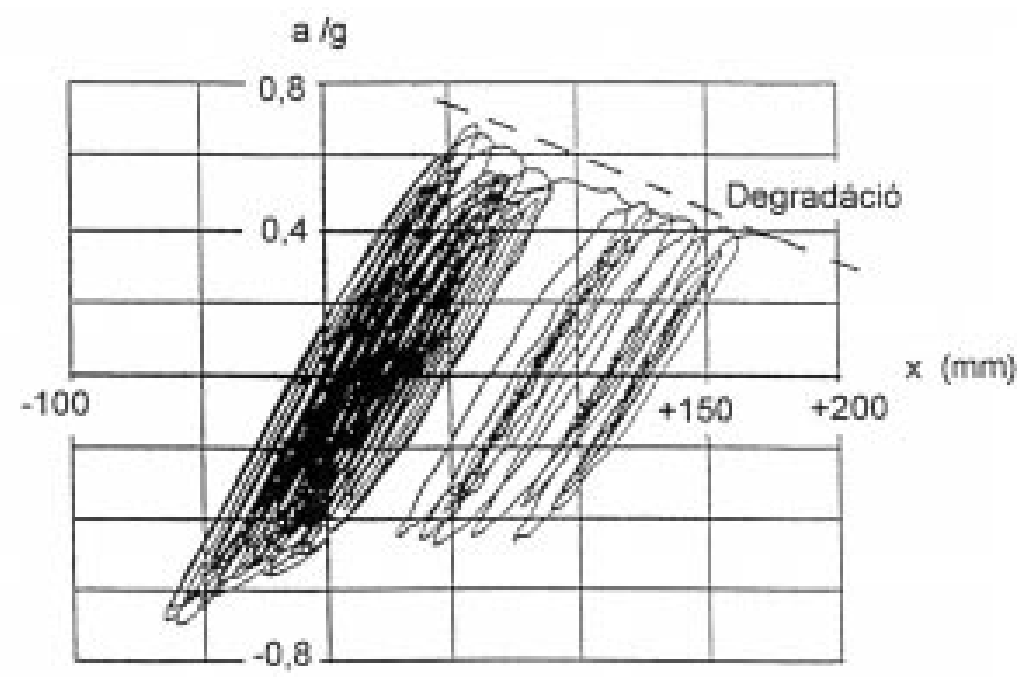

5. ábra. Degradációt mutató hiszterézis diagram 
A többszabadságfokú rendszerek (emeletes keretvázak) kutatására elméleti vizsgálatokat végeztünk, melyek arra utaltak, hogy a vázolt jelenség ezeknél is fennáll, de lehetséges, hogy eltérő mértékkel, hisz ezek a szerkezetek statikailag sokszorosan határozatlanok.

Vizsgálataink arra mutatnak, hogy a világszerte alkalmazott földrengési méretezés hibás. Bizonyos képleteket levezettünk a helyes méretezésre. Korrekt a méretezés akkor, ha a duktilitás helyenként jelentkező kedvező hatását tartaléknak tekintik, és nem, vagy csak erősen korlátozottan veszik figyelembe.

A földrengés során az épületkárosodás lágyítja az épületet, és így a rugalmas spektrumból azt a következtetést lehetett levonni, hogy a lágyulással a károsító hatás is csökken. A rugalmas-képlékeny spektrum alapján viszont egyértelmúen látszik, hogy a periódusidő növekedésével bizonyos esetekben a károsító hatás növekszik, és ez az épület összeomlásához vezethet.

\section{AZ ÚJABB KUTATÁSI VIZSGÁLATOK CÉLJA}

Az újabb OTKA munka [2] keretében a többszabadságfokú rendszerek részletesebb, kísérletekkel ellenőrzött vizsgálatát tüztük ki célul, a helyesebb földrengés elleni méretezési elmélet egyes kérdéseinek tisztázása érdekében.

Ennek keretében a Budapesti Müszaki Egyetem egyszabadságfokú rázóasztalán 2 sorozat acélkeret modellt vizsgáltunk, magyarországi jellegü földrengésre. A magyarországi földrengések domináns periódusideje 0,2-0,5 sec közötti. Ezt megközelítendő, a Geo-Risk Kft.-től beszereztük az általuk ajánlott 1996. évi szabadszállási földrengés három gyorsulási spektrumát. A három spektrum közül az első a rengés epicentrumához legközelebbi $(16 \mathrm{~km})$, a második távolabbi $(27 \mathrm{~km})$ és a harmadik még távolabbi mérésből származik, és ennek megfelelően lecsökken a gyorsulás csúcsértéke, és bizonyos mértékben módosul a spektrum alakja is.

A spektrumot megközelítettük egy olyan szimulált földrengés-idő-történettel, melyet Fourier-analízissel állítottunk elő, és spektruma megegyezik a Szabadszállás környezetében regisztrált földrengési spektrummal. Tekintve, hogy valamely terület felső rétegeinek geológiai tulajdonságai jól meghatározzák a földrengés periódusának jellegét, a gyorsulás nagysága torzítható. Így egy olyan földrengési spektrumot lehet nyerni, mely jól tükrözi a mintegy 20 éves gyakorisággal bekövetkező 5 magnitúdójú magyar földrengést. Így a kísérletek eredményei az elméleti következtetéseken kívül a magyarországi konkrét földrengésvédelemnek is támpontokat tudnak nyújtani.

A rázóasztalon először szabványos vizsgálóteszttel kimértük a modellek sajátfrekvenciáit, összehasonlítva azokat a különböző számítógépes programokkal nyert sajátfrekvenciákkal. Az eredmények természetesen nem egyeztek meg, de az 
eltérés nem volt számottevő. Két sorozatban vizsgáltuk a kísérleti modelleket, mindegyik sorozat egyszerre három különböző magasságú modellt tartalmazott. A gerjesztő gyorsulás nagysága igy a három modellen teljesen egyforma volt.

A rázóasztalon a földrengést szimuláló vizsgálatot mindhárom földrengési gyorsulási spektrumra elvégeztük. Az első sorozatban először féltömeg terhelést alkalmaztunk, és a gyorsulás nagyságát fokozatosan növeltük, 25\%-os értékkel kezdve, mert nem tudtuk biztosan, hogy a modellek hogyan fognak viselkedni a rázás során. Az első sorozat modelljei csomópontjainak hegesztései a teljesnek tervezett keresztmetszetű varratok ellenére gyengének bizonyultak, és kísérlet közben többször kellett a hegesztéseket javítani.

Ezért a második sorozat hegesztéseit már előre megerősítettük. Annak ellenére, hogy a sarkokra ráhegesztett $3 \mathrm{~mm}$ többletvarrat a statikai, illetve a dinamikai modellt nem változtatja meg, a modellek sajátfrekvenciái mintegy 20-40\%-kal megváltoztak, és a keretek merevebbé váltak, sajátfrekvenciáik a számítottakéval jobban egyeztek.

A kísérletek során a jellegzetes képlékeny viselkedést a 2. sorozat modelljein sikerült elérnünk, a 200 ill. a 400\%-os gyorsulás alkalmazásával. Ezt egymás után többször alkalmaztuk. A kísérleti modellek tervezési problémáit, a modellek leírását, a kísérletek ismertetését, a számítással való összehasonlítását és a végzett kísérletből levont tanulságokat és következtetéseket az OTKA jelentés [2] részletesen tartalmazza.

\section{A KÍSÉRLET LEBONYOLÍTÁSA}

A rázóasztal felhasználásával lehetővé vált a Szilárdságtani és Tartószerkezeti Tanszéken folyó, épületek földrengésre történő méretezésének ellenőrzése modell kísérletek végrehajtásával. A Magyarországon épített többemeletes házak három különböző magasságú (alacsony: 4 emeletig, középmagas: 10 emeletig és magas) csoportba lettek sorolva. Ezeknek az épületeknek a magassági, merevségi és tömeg-, ill. terhelési viszonyait reprezentáló egyszerú vázas modellek szolgáltak a kísérletek céljára. Az épületmodellek négyzetes keresztmetszetủ acélrudakból épültek fel. A csomópontokba futó rudak hegesztéssel voltak egymáshoz erősítve. A három modell 4, 8 és 12 szintes volt. Az alsó és legfelső szint kivételével először minden második szintre (félteher), majd minden szintre $19 \mathrm{~kg}$ tömegü betonlap lett erősítve úgy, hogy merevsége ne befolyásolja a modell merevségét. A modellek függőleges rúdjainak talpai a rázóasztalhoz erősített acélsínhez voltak erősítve.

A tesztek végrehajtása során a modellek mozgásának tanulmányozására minden második szinten gyorsulásérzékelőt rögzítettünk a betonlapokra a gerjesztéssel párhuzamosan. A vizsgálatra előkészített modellekről készült vázlat a 6. ábrán látható. 


\section{2. méröpont}

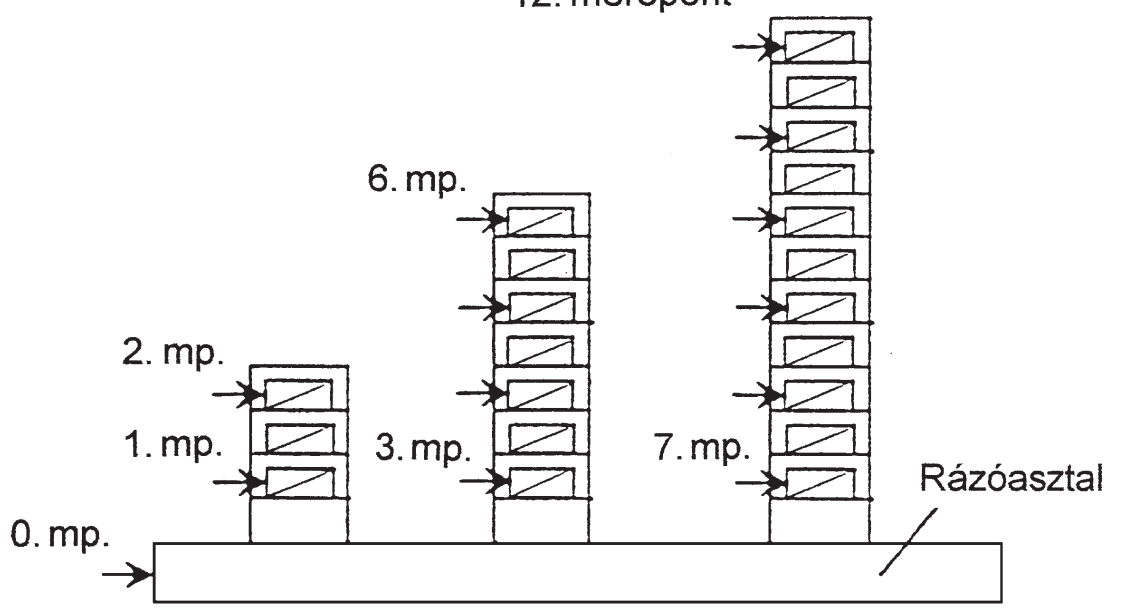

6. ábra. A vizsgálatra előkészített modellek vázlata

A vizsgálat során első lépésben meghatároztuk a modellek dinamikai paramétereit. A második lépésben szintetikusan elő́llított földrengés időjelekkel gerjesztettük a rázóasztalra erősített modelleket, és vizsgáltuk a hatásukat.

A több lépésben végrehajtott tesztelést két alkalommal végeztük el azonos szerkezetű modelleken. A második vizsgálat során a hegesztéseket előre megerősítettük, az első sorozatban előfordult, bosszantó varratrepedések elkerülésére.

Az alkalmazott vizsgálati eljárást az érvényben lévő nemzetközi szabványok elöírása szerint végeztük el. A modellek dinamikai paramétereit söprő szinuszos kutató teszttel derítettük fel. A rázóasztalt konstans gyorsulási amplitúdójú, folyamatosan növekvő frekvenciájú szinusszal gerjesztettük, ezzel egyidejűleg az előző ábrán látható mérési pontokban mértük a modellek válasz gyorsulás-idő függvényét.

A gerjesztés gyorsulási amplitúdóját elegendően magasra kellett választani ahhoz, hogy a modell minden sajátfrekvenciája kigerjedjen, ugyanakkor a sajátfrekvenciák környezetében le kellett csökkenteni, hogy lehetőleg ne lépjen fel a modellekben maradó károsodás, a szerkezet a rugalmas tartományban maradjon. Ebben az esetben a modell meghatározott paraméterei függetlenek a gerjesztés amplitúdójától.

A frekvenciaváltozás sebessége kellően lassú volt ahhoz, hogy a modell minden sajátfrekvenciája kigerjedjen. A gerjesztés frekvenciatartománya lefedte, ill. túlnyúlt a szeizmikus gerjesztés frekvenciatartományán mind az alacsonyabb, mind a magasabb frekvenciatartományban. 
A gerjesztés paraméterei:

Átfogott frekvenciatartomány: $\quad 0,4-40 \mathrm{~Hz}$

A frekvenciaváltozás sebessége: 1 oktáv/perc

A gyosulási amplitúdó: $\quad 1 \mathrm{~m} / \mathrm{sec}^{2}$

Jelkiadás frekvenciája: $\quad 200 \mathrm{~Hz}$.

A modell kényszerrezgésének mérésére 12 csatornán mértük a gerjesztésre adott válaszgyorsulásokat. További egy csatornán a rázóasztal gyorsulását mértük. A modellre erősített gyorsulásérzékelők mérési pontjai a 6. ábrán láthatók.

Az átviteli függvény grafikonjából meghatározhatók a szerkezet sajátfrekvenciái és a sajátfrekvenciához tartozó modális csillapítás értékei. A magnitúdó görbéből meghatároztuk a szerkezet sajátfrekvenciáit és a hozzá tartozó modális csillapítási értékeket. A dinamikai paraméterek biztonságosan akkor határozhatók meg a magnitúdó görbéből, ha a sajátfrekvenciák távol vannak egymástól, és a gerjesztés során a vizsgált szerkezet alakváltozása a lineáris tartományban marad.

A szerkezet sajátfrekvenciái megfelelnek a lokális csúcsokhoz tartozó frekvenciaértékeknek, míg a hozzájuk tartozó csillapítás értékét a félteljesítményhez tartozó frekvenciákból határoztuk meg: $\alpha=\left(\Delta \mathrm{f} / 2 \mathrm{f}_{0}\right) \cdot 100 \%$, ahol $\alpha$ a modális csillapítás a kritikus csillapítás százalékában kifejezve, $\Delta \mathrm{f}$ a fél teljesítményhez tartozó frekvenciasávszélesség, és $\mathrm{f}_{0}$ a sajátfrekvencia. (Lásd az 1. és 2. táblázatot.)

1. táblázat. 1. sorozat modelljeinek sajátfrekvenciái és csillapításai

\begin{tabular}{rccccc}
\hline \multicolumn{2}{c}{4 szintes modell } & \multicolumn{2}{c}{8 szintes modell } & \multicolumn{2}{c}{12 szintes modell } \\
$\mathrm{f}_{\text {saját }}(\mathrm{Hz})$ & $\beta(\%)$ & $\mathrm{f}_{\text {saját }}(\mathrm{Hz})$ & $\beta(\%)$ & $\mathrm{f}_{\text {saját }}(\mathrm{Hz})$ & $\beta(\%)$ \\
\hline 6,3 & 7.0 & 3,25 & 5,0 & 2,0 & 5,0 \\
17,5 & 6,6 & 9,9 & 6,5 & 6,4 & 4,3 \\
- & - & 17,0 & 4,6 & 11,0 & 5,1 \\
- & - & - & - & 15,6 & 4,9 \\
\hline
\end{tabular}

2. táblázat. 1. sorozat modelljeinek sajátfrekvenciái és csillapításai

\begin{tabular}{cccccc}
\hline \multicolumn{2}{c}{ 4 szintes modell } & \multicolumn{2}{c}{8 szintes modell } & \multicolumn{2}{c}{12 szintes modell } \\
$\mathrm{f}_{\text {saját }}(\mathrm{Hz})$ & $\beta(\%)$ & $\mathrm{f}_{\text {saját }}(\mathrm{Hz})$ & $\beta(\%)$ & $\mathrm{f}_{\text {saját }}(\mathrm{Hz})$ & $\beta(\%)$ \\
\hline 9,2 & 7,0 & 3,9 & 8,0 & 2,4 & 7,8 \\
26,5 & 3,0 & 12,1 & 2,4 & 7,6 & 3,1 \\
- & - & 20,6 & 3,2 & 13,0 & 2,7 \\
- & - & - & - & 18,4 & 3,0 \\
\hline
\end{tabular}


Érdemes az ilyen módon meghatározott sajátfrekvenciák pontosságát ellenőrizni az átviteli függvény valós és képzetes görbéinek a segítségével. Egyedülálló sajátfrekvencia esetén az átviteli függvény képzetes részének csúcsa, a valós részének null-átmenete van. A $28 \mathrm{~Hz}$ alatti frekvenciatartományban a két módszerrel számított sajátfrekvencia értékek azonos eredményt mutattak. A következőkben táblázatos formában megadjuk a modellek mért sajátfrekvenciáit és számított modális csillapításait (1. és 2. táblázat).

A modellek dinamikai paramétereinek meghatározása után szintetikus szeizmogramokkal gerjesztettük a modelleket. A kísérletek során a gyorsulási válasz értékeit mértük, az elmozdulásokat pedig a gyorsulásfüggvény kétszeri numerikus integrálásával állítottuk elő. Ennek során különböző szürésre volt szükség, és ezért az elmozdulásértékek nem tekinthetők pontosnak. A szeizmikus gerjesztés után a vizsgálatok befejezéseképpen ismét meghatároztuk a modellek dinamikai paramétereit, de nem találtunk eltérést az előbbiekhez képest.

A szeizmikus gerjesztésekhez három, 5\% csillapítású spektrumot adott meg a Geo-Risk Földrengésjelző Obszervatórium. A spektrumokból három szintetikus szeizmikus gerjesztő időfüggvényt állítottunk elő a spektrumoknak megfelelő frekvenciatartalommal. A rázóasztalos vizsgálatok számított teszt spektrumainak ezekre az ún. kívánt spektrumokra kellett illeszkedni.

A gyorsulás válaszspektrum olyan egyszabadságfokú lengő rendszernek a földrengés gyorsulási időjelre adott válaszgyorsulás abszolút értékének a maximuma a lengő rendszer sajátfrekvenciájának a függvényében, amely egy rugóból, egy pontszerü tömegből és egy a rugóval párhuzamosan kötött csillapító tagból áll.

A vizsgálatok előkészítése során az obszervatóriumtól kapott kívánt válaszspektrumnak megfelelő szintetikus szeizmogramokat iterációs eljárással állítottuk elő a rázóasztalon. Ez az iterációs eljárás biztosította, hogy a rázóasztal mért gyorsulásának időjeléből képezett válaszspektrum megegyezzen a kívánttal. (Az előkészítés alkalmával a modellek nem voltak felszerelve a rázóasztalra.)

Mindkét vizsgálatsorozatban a gerjesztés szintjét fokozatosan emeltük addig a szintig, ahol maradó (duktilis) alakváltozást tapasztaltunk valamelyik modellben. Így először a kívánt spektrum 25\%-ának megfelelő szinten, majd fokozatosan emelve azt 50, 100, 200 és 400\%-os terheléssel hajtottuk végre a szeizmikus gerjesztést. A kísérletsorozatoknak megfelelő gyorsulási és elmozdulási táblázatok és diagramok az OTKA jelentésben [2] találhatók.

A csillapítás értékelésekor megfelelő gondossággal kell eljárni, mert a kutató tesztekből meghatározott modális csillapítások az adott gerjesztési szintre vonatkoznak. Ha a rugalmas alakváltozás a teszt során végig a lineáris tartományban marad, akkor a kapott csillapítás végig érvényes, de azon túl megváltozik, sőt számolni kell a sajátfrekvenciák megváltozásával is. 
Figyelemre méltó, hogy a második sorozatban a modellek dinamikai paraméterei jelentősen megváltoztak az első sorozathoz képest. Mint korábban jeleztük, a második sorozatban a modellek hegesztéseit meg kellett erősíteni. A megerősítés hatására a varratok megfelelően ellenállóak lettek, ám ez a dinamikai paraméterek nem várt megváltozását okozta. A merevségnövekedés a 4 szintes modellnél mintegy $50 \%$, a két magasabb modellnél kb. 20\% frekvenciaváltozást okozott. Ez az elég jelentős eltérés valószínúleg annak a következménye, hogy az első vizsgálatsorozatban a modellek csomópontjai nem voltak kellően szilárdak, és így csomóponti merevségük is csökkent értékü volt. Így a gerjesztéssel megegyező irányú vízszintes rudak a számítottnál jobban elfordulhattak a függőlegesekhez képest.

A képlékeny alakváltozások tartományán a 10,70 sec pillanatban mért eltolódás és gyorsulás értékeit a 12 szintes modell esetén a 7. ábrán, a különböző gyorsulásokkal megrázott 12 szintes modellek maximális gyorsulásait és eltolódásait pedig a 8. ábrán mutatjuk be. Figyelembe kell azonban vennünk, hogy a különböző szintekre mért maximális értékek nem azonos időpontban következtek be, és ezért a hajlítási igénybevételekre nem jellemzők.

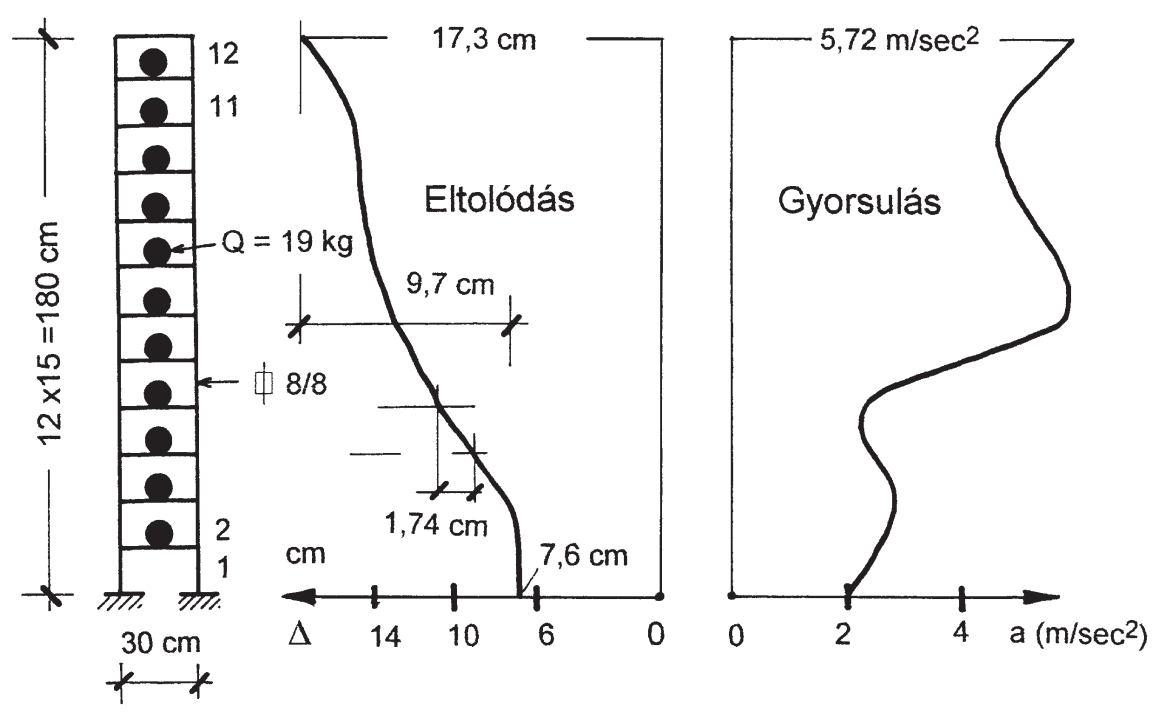

7. ábra. Az AT1G400 jelű, 12 szintes modell eltolódása és gyorsulása 400\%-os gerjesztésre az 1070 sz. időpontban (kezdéstől 10,70 sec) 

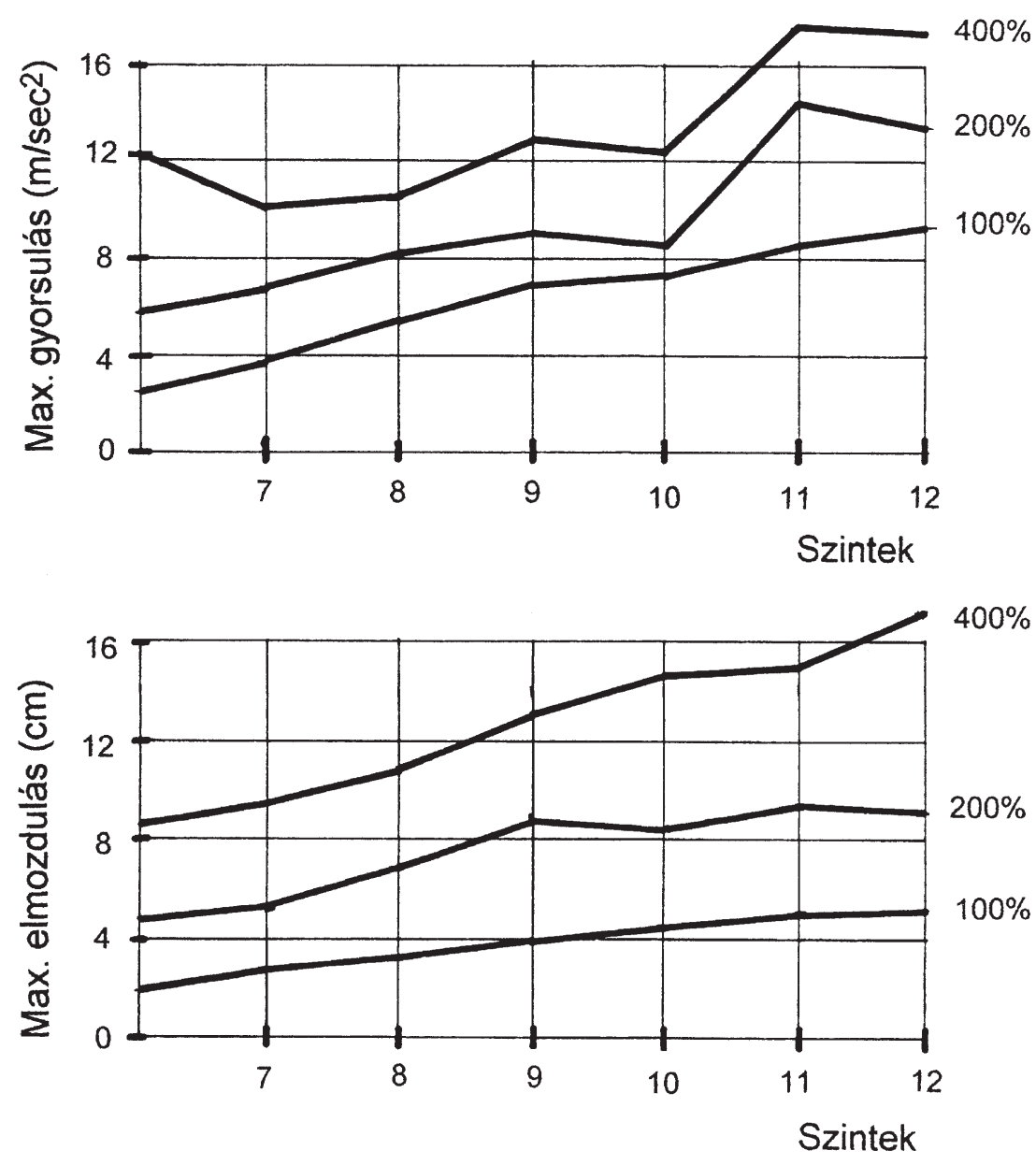

8. ábra. A 12 szintes modell maximális gyorsulási és maximális eltolódási ábrái

\section{RUGALMAS-KÉPLÉKENY VIZSGÁLAT SZÁMÍTÁSSAL}

A modellkeretek rugalmas-képlékeny számításához alapadatként szükséges a keret rugalmas megoldása a vízszintes földrengésteher hatására, ezért először azt kellett meghatároznunk. Ennek keretében a sajátrezgésszámokat kézi és gépi számítással, a RISA2D, az ETABS és az MSC-NASTRAN programokkal határoztuk meg. Ezek az értékek viszonylag jó egyezést mutattak a kísérleti eredményekkel. A számítógépi számításokkal meghatározott maximális elmozdulások és gyorsu- 
lások már tarka képet mutattak. A leginkább eltérő eredményeket az MSCNASTRAN program adta. A kísérlettel meghatározott maximális elmozdulás és gyorsulásértékeknek a számítottal való összehasonlítását a 3. táblázatban láthatjuk.

3. táblázat. A 12 szintes, 1. spektrum szerinti, 100\%-os gyorsulással gerjesztett, teljes terhü keretmodellek különböző programokkal számított gyorsulás és eltolódásértékeinek összehasonlítása a kísérleti értékekkel

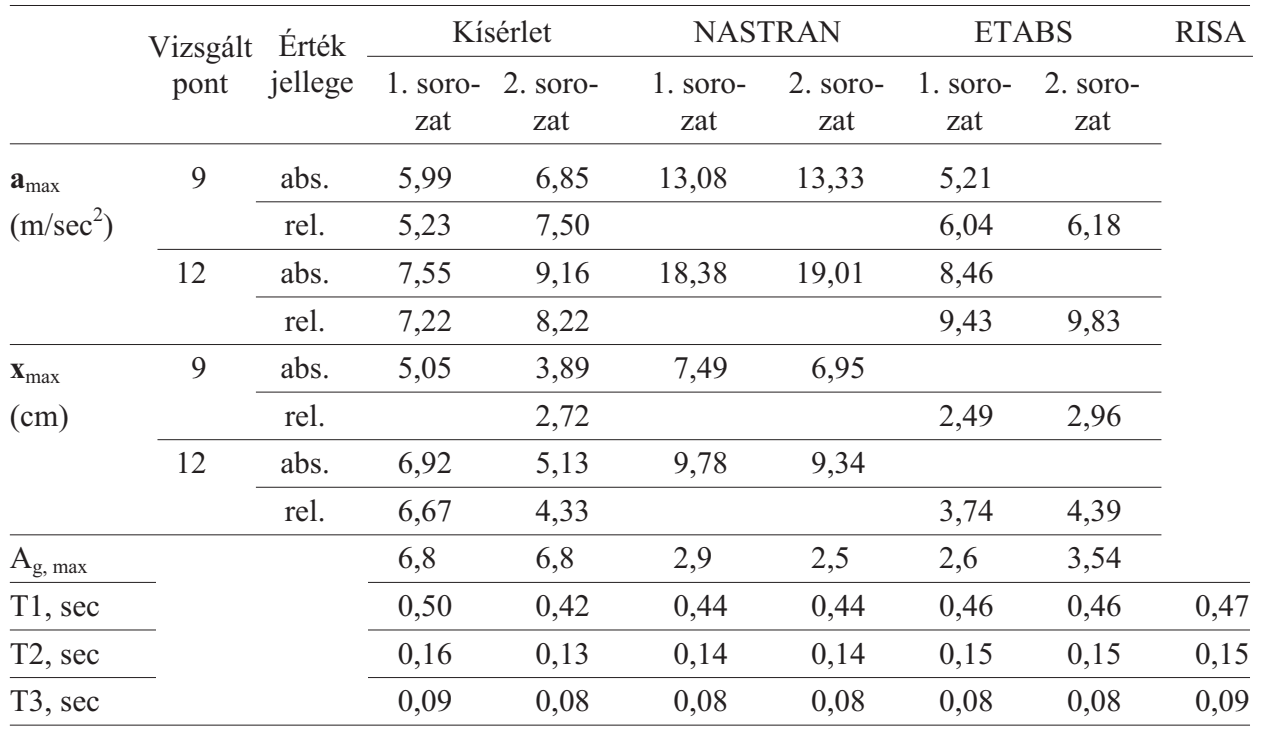

Rugalmas szerkezetet feltételezve elvégeztük a számítást a földrengésvizsgálatok esetén szokásos spektrális számításmóddal, a földrengési gyorsulási spektrumból, és az alapgyorsulásból számított háromszögmegoszlású erőrendszert múködtettük a szerkezetre. Így a számítást egyszerüen lehetett a számítógéppel elvégezni. Az eltolódásokat és a hajlítónyomatékokat a P-FRAME program segítségével határoztuk meg. A gyorsulási spektrum és a szerkezet tömegéből számított eltoló erő 2,30-szorosa, az alakváltozás pedig 1,42-szerese a kísérleteknél mért értéknek.

Így úgy látszik, hogy a spektrum alapján való méretezés túlzott értékeket ad.

Miután a képlékeny vizsgálathoz beszerzett NASTRAN program végül is nem bizonyult alkalmasnak a keretmodell rugalmas-képlékeny dinamikai vizsgálatára, a képlékeny vizsgálatot csak szúkített keretben, kézi számítással, energiamódszerrel végeztük el, az $L_{\text {külső }}$ külső munka és az $L_{\text {belsố }}$ belső munka egyenlőségének tételével. E tétel ugyanis mindig érvényes, a rugalmas tartományban éppúgy mint a képlékeny szakaszon, mind a konzervatív, mind a nemkonzervatív rendszer esetében. 
Az alakváltozási munkák egyenlőségének a tétele a következő:

$$
L_{\text {külső }}=L_{\text {belsö }}
$$

Az egyes munkák kifejezése a következő:

$$
\begin{gathered}
L_{\text {külsỏ }}=\int_{0}^{\Delta} a_{g} \cdot M \cdot d \Delta=a_{g, \text { átlagos }} \cdot M \cdot d \Delta \\
L_{\text {belsỏ }}=T_{u}(\Delta-\Delta e / 2)+\frac{N \cdot \Delta^{2}}{2 \cdot L}+\frac{1}{2} M \cdot v^{2}
\end{gathered}
$$

A $v$ sebesség a $\Delta / t_{\text {vizsgált }}$ kifejezésből becsülhető.

A számítást a 12 szintes keret esetében végeztük el. Példaképpen a teljes terhelésủ, 1. sorozatú, 400\%-os gyorsulással gerjesztett keretet választottuk, mert ezen kétségen kívül képlékeny alakváltozást tudtunk elérni a kísérlet során.

A gyorsulásértékeket a rázóasztal gyorsulásának kinagyított diagramjából dolgoztuk ki, az egyes pontok mért gyorsulásadatai figyelembevételével. A vizsgált időszakaszon az átlagos gyorsulás alapján felírva a külső és belső munka egyenlőségét, a kinetikus energiát, a $\mathrm{P}-\Delta$ hatás nélkül az eltolódásra $\Delta=0,67 \mathrm{~cm}$ érték adódott, ez jó egyezést mutat a kísérleti $\Delta=0,76 \mathrm{~cm}$ értékkel. A 12 szintes rugalmas képlékeny modell 12 mérőpontjának elmozdulás és gyorsulásértékei a 9. ábrán láthatók.

\section{AZ ELVÉGZETT VIZSGÁLATOK ÖSSZEHASONLÍTÁSA ÉS TANULSÁGAI}

Kísérleteinknél meglehetősen pontosan ismertük a vizsgált modellkeret szerkezeti jellemzőit (merevség, méretek, anyag, tömeg), és a kísérleteknél alkalmazott, ismert spektrális adatokból számoltunk, mégis jelentős eltérés adódott a kísérlethez képest.

Ennek több oka lehet, melyeket megkísérelünk felsorolni.

- A spektrum a csúcsokra illesztett burkológörbe. A csúcsok viszont nem jellemzőek a szerkezetre, mert a gyorsulásgörbe erősen csipkézett (a csipkézés nagyfrekvenciájú, kis periódusidejü). Ezt a csipkézettséget láthatjuk a 10. ábrán, összehasonlítva a szerkezet periódusával. Látható az ábrából, hogy a csipkék periódusa sokkal kisebb a szerkezeténél. Ezért a csipkék hatására a szerkezet nem tud kigerjedni, csak esetleg csökkentett mértékben a csipkék átlagára. Így a szerkezet keve- 
Eltolódás $(\Delta=\mathrm{cm})$

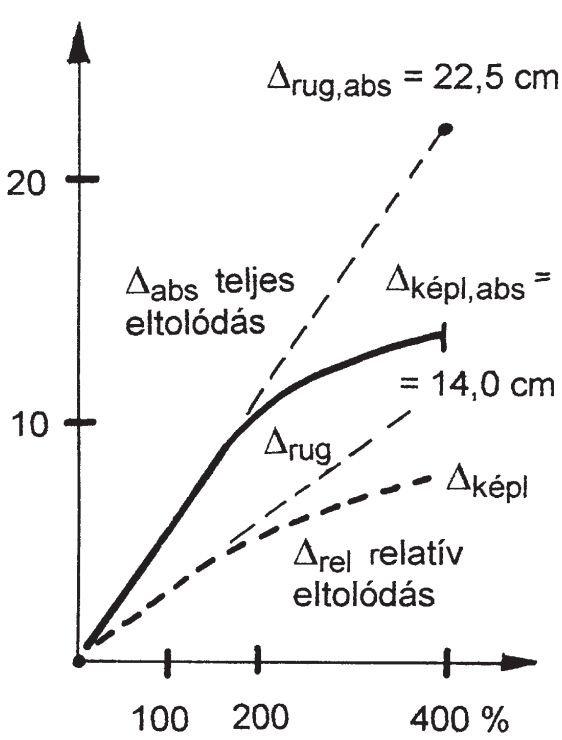

Gyorsulás $\left(a=m / \mathrm{sec}^{2}\right)$

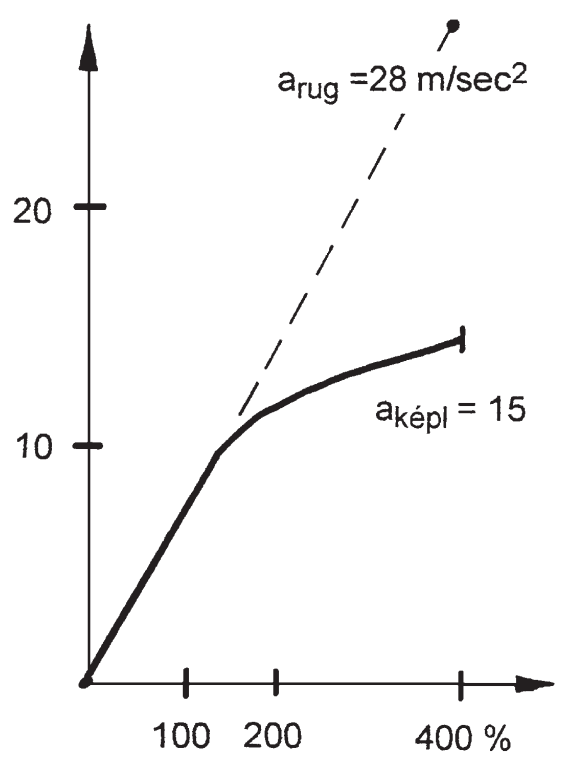

9. ábra. A 12 szintes modell 12. mérőpontjának elmozdulás és gyorsulásértékei

2. sorozat, AT1G100\% 12. mérési pont
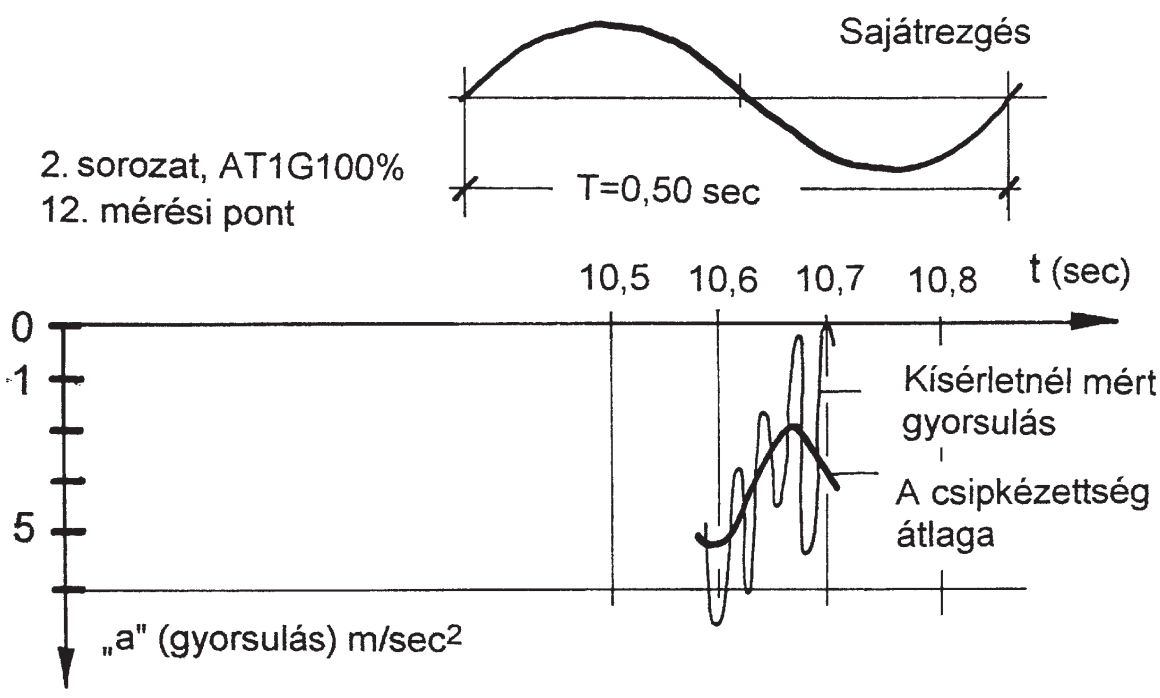

10. ábra. A mért, kinagyított csipkés gyorsulásgörbe összehasonlítva a szerkezet periódusával 
sebb energiát vesz fel, mint amekkora a csipkecsúcsokra illesztett spektrumból következne.

Valószínú, hogy az 1/100 secundumos adatfelvétel túlságosan ritka, és sűrűbb adatfelvétel lenne szükséges. Ezért a csúcsokra illesztett spektrum alapján a szokott spektrális analízissel végzett vizsgálat igen pontatlan eredményekhez vezethet.

Az egész számítás maga (különösen többszabadságfokú rendszernél) rendkívül érzékeny, már a rugalmas tartományban is, de a képlékenyben fokozottan, mert nagy számok kis különbségéből adódik a megoldás. Ez nem a felírás módjából következik, hanem a probléma jellegéből, mert a tönkremenetel azt jelenti, hogy még maradt mozgási energia a rendszerben. A mozgási energia viszont a külső munka és a belső alakváltozási munka (melyben szerepel a csillapítás energiaelnyelése is) különbsége. E körülmény azt is megmagyarázza, hogy miért érzékeny a megoldás az egyébként nehezen és pontatlanul meghatározható csillapítás mértékére.

A korábbi elméleti, kísérleti, valamint a mostani kísérleti kutatásaink eredményei szerint a világszerte kedvezőnek vélt duktilitási hatások sokkal kevésbé csökkentik a szerkezet igénybevételét, mint ahogy azt a javasolt spektrális számításhoz a földrengésméretezési előírások feltételezik. Ehhez még hozzájárul az, hogy a szerkezet sajátperiódusidejét becslő képletekkel számítják, és ez a pontatlanul számított érték a spektrumgörbe eső szakaszán jelentős hibát okozhat. Figyelembe kellene venni, hogy földrengési gerjesztés viszonylag széles frekvenciasávban következik be (ez Magyarországon 2-5 Hz, azaz a periódusidő 0,2-0,5 sec), és az épület sajátfrekvenciáját csak közelítően lehet meghatározni, ezért a rezonancia széles sávban előfordulhat. Ezek alapján indokoltnak látszik a $\beta=2,5$ maximális szorzót alkalmazni.

Úgy gondoljuk, hogy a számítógépes programokkal szerzett tapasztalatainkat is célszerü leírni, hogy mások is okuljanak belőle.

- A végeselemes (FEA) analízist használó programok egyrészt nem teljesen megbízhatóak, másrészt felépítésük és adatbeviteli módjuk sokszor lehetetlenné, máskor igen nehézzé teszik a korrekt modellezést, és ez természetesen az eredményben jelentôs eltérést okozhat. Jó példa erre a NASTRAN program, mely a propagandafüzet és a leírás szerint is képes a képlékeny számításra és a dinamikai számításra. A valóságban azonban a képlékeny számítást csak a statikus jellegú terhekre tudja. De a rugalmas tartományban is az azonos (a kísérleteknek megfelelö) bemenő gyorsulási adatsorra mintegy kétszer akkora válaszértékeket adott, mint az ETABS program, ill. a kísérletek.

- Ami az ETABS programot illeti, a rugalmas tartományban megbízhatónak lehet tekinteni (képlékeny modul nincs Magyarországon). Az adatbevitel korrekt és egyszerü, ezenkívül számos közelítő eljárással is ellenőrizték. Ennek valószínúleg az az oka, hogy az ETABS programot direkt vázas épületek földrengési vizsgála- 
taira fejlesztették ki, míg a NASTRAN egy általános „mindentudó” program. Az ETABS hátránya, hogy csak keretszerkezetet, ill. merevített keretszerkezetet tud számítani, nagy előnye viszont, hogy egy számítás néhány perc alatt lefut, míg a NASTRAN-nál ugyanarra a feladatra 1-2 órát kell várni, ugyanazon a Pentium-II gépen.

\section{ÖSSZEFOGLALÁS}

A Budapesti Múszaki Egyetem egyszabadságfokú rázóasztalán 3 sorozat acélkeret modellt vizsgáltunk (alacsony, középmagas és magas épületet modellezve) 0,2-0,5 sec közötti domináns periódusú magyarországi jellegű földrengésre. Összesen harminc kísérletet végeztünk. A kísérletek során a jellegzetes képlékeny viselkedést sikerült elérnünk a 200 és 400\%-os gyorsulás alkalmazásával.

A modelleket több számítógépes programmal (RISA-2D, ETABS, MSC/NASTRAN) is megvizsgáltuk a kísérletivel azonos gerjesztéssel, így az eredményeket össze tudtuk hasonlítani a kísérleti adatokkal.

A részletes zárójelentésben ismertettük a kísérletek tervezési és megvalósítási problémáit, a modellek részletesebb leírását, szemléltetésként bemutattuk a kísérleti eredményeket és az eredmények összehasonlítását, valamint a leszürhető tanulságokat, tapasztalatokat és következtetéseket.

\section{IRODALOM}

[1] Dulácska E.: A duktilitás és a P-Delta effektus együttes hatása a nyomóerővel is terhelt szerkezetek földrengés elleni méretezésében. Épités- Épitészettudomány 25 (3-4), 1995.

[2] Dulácska E.: Nemrugalmas anyagú, többszabadságfokú rendszerek dinamikai stabilitásállapotának vizsgálata (01571. OTKA zárójelentés, I-II.). BME Szilárdságtani Tanszék. Budapest, 1998.

[3] Dulácska E.: Tartószerkezetek, földrengéskockázat. Magyar Tudomány 1999/1.

[4] Paulay-Bachmann-Moser: Erdbebenbemessung von Stahlbetonbauten. Birkhauser V., Basel-Boston-Berlin, 1990. 


\section{THE DYNAMIC STABILITY CONDITION OF SYSTEMS MADE OF INELASTIC MATERIALS WITH SEVERAL DEGREES OF FREEDOM}

\section{Summary}

Three series of steel frame models (modelling low, medium and high building) were tested on the shaking table of the Technical University of Budapest, exciting them by accelograms of Hungarian earthquakes with the period of $0.2-0.5 \mathrm{sec}$. Altogether 30 experiments were conducted. During the tests the characteristic plastic behaviour could be attained on the models with an exciting acceleration of 200 and $400 \%$. The models were examined by several computer programs (RISA-2D, ETABS, and MSC/NASTRAN) with excitation coinciding with that in the experiment, hence results could be compared to experimental data.

In the detailed summary a complete account is given on the design and execution problems of the experiments, on the detailed description of the models; as illustration the experimental and computational results and their comparison are shown, as well the experiences and conclusions that can be drawn. 
